DOI: 10.24234/wisdom.v15i2.348

Halyna MOROSHKINA,

Ganna PRIHODKO,

Oleksandra PRYKHODCHENKO

\title{
PROJECTIONS OF INTERMEDIALITY IN A LITERARY TEXT
}

\begin{abstract}
The article is devoted to the study of linguistic manifestations of intermediality in English-language literary texts of the $20^{\text {th }}-21^{\text {st }}$ centuries. Intermediality is understood as a special type of structural interconnections within a work of art, based on the interaction of various types of art-languages in a system of a single literary text. Particular attention is paid to the analysis of such figurative structures that enclose information about another type of art. In the course of the analysis, it was established that the implementation of intermedial connections of literary, musical and visual texts interacting in the space of the semiosphere is carried out by borrowing of compositional-structural and plot-shaped means, which leads to the creolization of the transmitted message, providing a pragmatic effect on the recipient with a combination of verbal-iconic elements. The intermedial mechanism of combining codes of different semiotic systems contributes to the transfer of an artistic image in the text at different levels of abstraction.
\end{abstract}

Keywords: intermediality, semiosphere, literary text, creolization, iconicity, code.

Introduction

The present-day reality, marked by the processes of globalization, has led to the change in the paradigms of scientific research in general, and in the field of linguistic science in particular. Understanding of the history as a multidimensional construct which goes beyond the frame of verbal representation allows us to reinterpret the mechanisms of symbolic development in the space of culture. Scholars have noticed that in recent times, more and more often, the scientific study of any research object is carried out through the simultaneous use of the efforts of several different disciplines. Interdisciplinarity with assurance declared itself as a way that can direct modern scientific studies into new searches.
Interest in studying the problem of intermediality was observed only at the end of the $20^{\text {th }}$ century. The basis for new research was the necessity to reorganize the thousand-year-old traditions of the synthesis of arts from the standpoint of modern literary, cultural and linguistic ideas. More than one generation of scientists devoted their works to this problem, calling the same phenomena in different ways (synthesis of arts, syncretism, intertext and intermediality).

Numerous modern native and foreign philological studies focused on the concept of "intermediality" show a significant interest in this complex phenomenon. However, the pluralistic interpretation of the term "intermediality" and the lack of a single definition, despite the stalwart efforts of many scholars require finding the caus- 
es of such state of affairs, etymological analysis of components, its differentiation from other related terms, analysis of the evolution of this concept.

The interdisciplinary approach to the analysis of linguistic phenomena allowed us to move away from the study of isolated units and contributed to the comprehensive coverage of the object of observation and its placement in the general context of culture. The time required the introduction of new institutional strategies into the research process. Works of M. Bakhtin (1986), R. Bart (1989), J. Derrida (2001), Y. Kristeva (2004) served as the theoretical foundation for the transition from intersubject methodology to interdisciplinary one. Scientists paid attention to the issues of dialogical character, textual polyphony, metatext, intertextuality as an essence of arts.

The term "intermediality" (Eng. Inter + media / art = intermedia / interart) was proposed by the German scientist A. Hansen-Löve (1983), and the motivation of the notion was given by the philosopher I. P. Ilyin (1998), who derived a universal cultural language from the languages of each art. In a broad sense, intermediality is the creation of an integrated polyartistic space in the cultural system (artistic metalanguage of culture, according to I. P. Ilyin). In a narrow sense, it is a particular type of intertextual relationships in a work of art, where different types of art interact.

The purpose of the proposed article is to determine the specificity of the implementation of intermediality in literary texts from a cognitive perspective.

The material, which is subjected to analysis were works by E. M. Forster, W. S. Maugham, J. Barth. (the total volume 2606 pages).

Research Methods. In order to achieve this goal, the following methods were used: the her- meneutic method promotes a comprehensive analysis and interpretation of intermedial relations that arise in the novels; descriptive-interpretative method is involved in explaining the peculiarities of the revealed facts, interpretation and commentary on the research material. Considering the historical and literary specifics of the concept of "intermediality" which appears in the second half of the twentieth century, some poststructuralist and deconstructivist approaches are taken into account, as well as the technique of "close reading", which allows identifying veiled and unconscious references between texts of novels and other works of art.

\section{Intermediality as a Variety of Intertextual Interactions}

A work of verbal art is not only intertextual and consists of quotes from other literary texts, but also it is characterized by intermediality, that is, comprises "quotes" borrowed from texts created in the languages of other types of art (Sedykh, 2008, p. 210). Such artistic "citation" was widely used by the symbolists of the $19^{\text {th }}$ century, who resorted to both literary and graphic texts of previous cultures, rethinking them in the context of new work. In this interpretation, "text" is understood broadly: not only as a literary one, but also as a "text of art", "text of culture", and "supertext" (Plett, 1991, pp. 3-29).

Intermediality is a more complex phenomenon in culture than syncretism. It is a key that allows us to open the code of the author's message in cases where the synthesis or dialogue of arts is observed. In such perspective, in the framework of our study, it is essential to reorganize the heritage of previous eras in the context of intermediality, because this notion implies new approaches to understanding the phenomenon of 
the interaction of arts. Besides, it also puts literature at the heart of the problem as the unique type of art that integrally fixes reality in the form of text canvases.

Since the 70 s of the twentieth century, the concept of "intermediality" began to appear in the terminological apparatus of philosophy, philology and art history, and according to E. P. Shiniev (2009), it is used together with the concepts of "intertextuality / intertext" and "interaction of arts". It must be noted that phenomenon of intermediality has been known since ancient times: in the poetry of Antiquity, there were explicit comments on intermedia processes "painting as silent poetry"; the inseparable connection between music, poetry, painting and philosophy was noticed in the Renaissance; poets of Enlightenment associate the effect of works of art with the structural specificity of the intermedia; representatives of Romanticism believe that the light that radiates the unity of different media and arts, affects the aesthetics of Romanticism; the poetry of the twentieth-century is not satisfied with words, oral or written, and resorts to music, plastic arts, and cinema. So, the main idea on which theorists focused was to study the relationships between different kinds of media.

The modern definition of the term intermediality was acquired in the work by the German scientist J. E. Müller. The scientist interprets it as an interdisciplinary approach to the analysis of polycode texts, where different media are in constant interaction and cannot be explained as separate isolated phenomena, united by simple adding to each other (Muller, 2010, pp. 15-38).

Canadian researcher S. Marinello, who was at the origins of the intermedia field of research, considers intermediality as a polymorphic concept. The main thing for her is to determine the goals of epistemological study in times of power- ful media transformations. She notes that the presence of media makes it possible to observe an event, a meeting or a common experience. Media consistently presupposes the existence of other media, i.e. media is always intermedial (Mariniello, 2003, p. 48).

Numerous publications of scientists are aimed at studying the correlations between different types of media. Thus, E. Meschoulan emphasizes that modern belief, unlike the classical one, perceives the object under study as a node of relations with other objects (Méchoulan, 2003, pp. 9-27).

The scholars of the $21^{\text {st }}$ century focus on the exploration of intermedia connections in the literary-text domain. Media are defined as channels of artistic communication between the languages of different arts, which contribute to the awareness of the differentiation between the concepts of "intertextuality" and "intermediality" (Olizko, 2007).

In the system of intertextual relations, connections are sought within a single semiotic chain, while in polycode texts organized on the principle of intermediality they exist within different semiotic ranges. So, as the researcher $\mathrm{N}$. V. Tishunina (2001) highlights, in the system of intermedial relations at first, one artistic code is translated into another as a rule, and then their interaction takes place, but on a semantic level not on a semiotic one (pp. 149-154). Consequently, the inclusion of elements of other arts in uncharacteristic and unexpected for them verbal range modifies the very principle of interaction of the arts in a significant way.

That is why in case of intermediality we are not dealing with citation, but with the correlation of texts. As a result, intermediality is the presence in a work of art such figurative structures that include information about another form of 
art. Thus, the concept of intermediality is revealed in both narrow and broad senses (Tishunina, 2001).

I. Rajewsky proposes a fascinating interpretation of intermediality. The scholar defines it in a broad sense as any phenomena that occur on the border of the media, and this is what distinguishes it from intra and -transmediality. However, in her opinion, this interpretation of the concept does not reflect the differences in the manifestation of the interaction of different arts. She suggests considering intermediality in the narrow sense as a category of detailed analysis of the text or other medial product. The scientist distinguishes three different interpretations: intermediality as a medial transposition (emphasis is on the transformation of a derived media product); intermediality as a unity of media (at least two different forms of arts, each has its materialness and contributes to the creation of a coherent text); intermediality as intermedia references (verbal reconstruction of elements of another art form and allegedly deliberate distorted depiction of an element of one art form by another) (Rajewsky, 2005, pp. 432-464).

The pluralism of the definition of term "intermediality" is obviously associated with its use in two different spheres of theoretical research: first, to denote the interaction of different media in one text, and secondly, to analyze it as a category of criticism of these media configurations.

In the perspective of intermediality, the notion of text acquires a broader meaning: film, theatrical production, painting can be perceived as a text. The text loses its objectivity in the generally accepted meaning because of interdisciplinary studies, namely, intertextuality, interdiscourse studies, which allow not only to decode the sense of the text in general but also to analyze the means of its formation.
Present-day researchers tend to analyze the text as an object of culture. They take into consideration both the study of content (generation of the meaning) and means of its reflection in the text (Bekhta, 2013; Vorobyova, 2008; Peach, 2016; Wolf, 1999).

The famous philosopher I. P. Ilyin proceeds from the fact that any sign system, both artistic and non-artistic, being structured into a text, becomes a source of information and forms part of the information space. "By the ambiguous term "media" we mean not only linguistic means of expressing thoughts and feelings but also any sign systems in which a message is encoded. From a semiotic point of view, they are all equal means of transmitting information, whether it is the writer's words, colour, shadow and artist's line, sounds (and music as a way of fixing them) by a musician, an organization of volumes by the sculptor and architect, and final arrangement of the visual row on the screen plane. All this represents those media that are organized in each kind of art according to its own set of rules, according to a code representing the specific language of each art. Together, these languages form the "collective language" of the culture of any particular historical period" (Ilyin, 1998, p. 8).

If "media" are defined as channels of artistic communication between languages of different types of art, then intermediality involves the transfer of one semiotic code to another within the framework of a text. Moreover, the insertion of elements of other types of art in a verbal set unusual for them transforms the principle of the interaction of arts. Here we observe the interconnection of signs" (Tishunina, 2001, p. 153).

As a result, using various codes in the interpretation of a work of art becomes possible due to the mark of openness, which allows us to consider every point of a literary text as a separate 
"organism", which is capable of self-development. The literary text repeatedly recreates and dynamically develops its intermedial structure by means of the external semiotic environment of the semiosphere and applying new codes of perception. In other words, intermedial self-organization is understood as the ability of elements of a nonequilibrium system of a literary text interacting with many other texts and sign systems to come to the ordering of its internal structure.

Intermedial Relations in a

$$
\text { Literary Text }
$$

While analyzing a literary work in which arts interact, it is necessary to find a pictorial code by means of which it will be possible to decipher the smallest shades of artistic content. Intermedial analysis of the text is based on the thesis that all media (artistic means and methods of different types of art or the arts themselves) are a special way of conveying artistic information and semantically they are equal (Wolf, 1999).

Consider the following example:

"Lilia had achieved pathos despite herself,

for there are some situations in which vul-

garity counts no longer. Not Cordelia nor

Imogen more deserves our tears" (Forster, 2008, p. 44).

Here we observe the inherent for any Englishman Shakespearean implication that arises in connection with the images of Lilia, who was desperate and died in marriage, and her husband, Gino. The author ironically compares her with Shakespeare's characters.

Another reference to W. Shakespeare is given by the author while describing the trip of Henrietta and Philip to Italy in order to "save" the child of the deceased Lily:
"And on the second day, the heat struck them, like a hand laid over the mouth, just as they were walking to see the tomb of Juliet. From that moment everything went wrong. They fled from Verona. Harriet's sketch-book was stolen, and the bottle of ammonia in her trunk burst over her prayer-book, so that purple patches appeared on all her clothes" (Forster, 2008, p. 67).

The reference to the famous heroine of $\mathrm{W}$. Shakespeare's work gives a distinctive colouring to all events of the novel. In the heroine's homeland, where the most famous love story in the world took place, everything starts to go against the plan: heat which is unusual for England, the theft of sketchbooks (the artistic distance and contact between the sketch-artist and objects of his interest disappear without a trace), and the damage of the prayer book (a symbol of the abandonment of religion in a traditionally Catholic country, which can explain many events in Italy, as Henrietta behaves contrary to God's law). Moreover, finally, the unfortunate love story of Juliet and Romeo finds its parallels with the far-fetched love and unhappy marriage of Lily.

It is important to note that the pseudo-tragic image of Lily is even more expanded by referential allusions to Dante Alighieri's works. Hence, at the beginning of the novel, when relatives see Lily and Carolina off on a trip to Italy as if predicting her fate, Philip says:

"Here beginneth the New Life" (For-

ster, 2008, p. 51).

The same line appears in the middle of the story when they learn about Lilia's death and the birth of a child, but now this is a prediction about changes in his life, and the life of Carolina and Gino.

Speaking of referential intermediality, one cannot but mention the biblical allusions and 
quotations that are met in the novel:

"Blessed be the Lord my God who teacheth my hands to war and my fingers to fight" (Forster, 2008, p. 109).

Here we see an allusion to a quotation from David's psalms, thanks to which Lilia gains confidence and determination, and then kidnaps the child in order to save the reputation of their family, but as a result, it only leads to the child's tragic death.

It should be mentioned that the most vivid example of intremediality in the novel is a musical-literary and dramatic synthesis. If we speak about theatrical episodes in the novel, then everything that happens in Italy is sometimes presented to the heroes as another performance (due to the particular dynamism, verbal arrangement of the text), and they both become actors and spectators as in the following fragment:

"She finished; and he was dumb, for she had spoken truly. Then, alas! The absurdity of his own position grew upon him, and he laughed - as he would have laughed at the same situation on the stage" (Forster, 2008, p. 46).

It is the presentation of the first quarrel between Lilia and Gino. The author, like a playwright, tries to convey the actions of the characters, their characteristics. The passage itself seems to resemble a theatrical remark, a clue for the actors.

Sometimes the theatricality is presented by the author as an Italian national feature of character through Philip's perception, who is a true connoisseur of Italian culture:

"The Italians are essentially dramatic; they look on death and love as spectacles. I don't doubt that he persuaded himself, for the moment, that he had behaved admirably, both as husband and widower" (Forster, 2008, p. 77).
In this case, the author presents the traditional associative opposition life/death-game on the material of the conflict of cultures. This opposition is based on the famous Shakespearean aphorism "The whole world is a theatre, women, and men are all actors in it". As a result, the world-theatre appears in this episode as Gino's skillful attempt (a true Italian and, therefore, a born actor or an experienced spectator, whom E. Forster describes with irony) to play for himself in the way to convince himself and other people in his rightness and continue life in illusion (in such illusion live the main characters, who are the English).

It is obligatory to keep in mind that the emotional sphere as an incentive for creative inspiration is essential for the writer, as well as self-knowledge and self-understanding. Nevertheless, only an actor can achieve such reflection, because it is he who sees the whole of humanity from the outside, watches it and plays it on the stage, perceiving and realizing the actions and characters of this world, going out on a kind of platform, climbing the stairs and thereby approaching a little closer to God. At the same time, the writer and artist are also able to reach a similar level, but this is not mandatory in their creative work, they are more flexible in the process of creation:

"It was strange and fantastic. It was a vision of the beginnings of the world, the Garden of Eden, with Adam and Eve - it was a hymn to the beauty of the human form, male and female, and the praise of Nature, sublime, indifferent, lovely, and cruel. It gave you an awful sense of the infinity of space and of the endlessness of time. Because he painted the trees I see about me every day, the cocoa-nuts, the banyans, the flamboyants, the alligatorpears, I have seen them ever since differ- 
ently, as though there were in them a spirit and a mystery which I am ever on the point of seizing and which forever escapes me. The colours were the colours familiar to me, and yet they were different. They had a significance which was all their own. And those nude men and women. They were of the earth, and yet apart from it. They seemed to possess something of the clay of which they were created, and at the same time something divine. You saw man in the nakedness of his primeval instincts, and you were afraid, for you saw yourself", (Maugham, 2008, p. 214).

This fragment is a description of Strickland's last masterpiece. It is a picture to which he strove all his life. This is a panorama that depicts the essence of the whole universe, the whole world, all life, creating which he was likened to the ancient gods. This is a brilliant example of recoding in intermediality:

A unique aspect of the particular emotional form of the synthesis of painting and poetry in the novel becomes an antique element based on the Dionysian beginning and associated with the pictorial primitivism of Gauguin, who is the prototype of Strickland. Firstly, the hero himself is perceived by the creative people around him (but not by philistines and writers) as a creator, a symbol of creative instinct and creative need:

"There was in him something primitive.

He seemed to partake of those obscure forces of nature which the Greeks personified in shapes part human and part beast, the satyr and the faun. I thought of Marsyas, whom the god flayed because he had dared to rival him in song. Strickland seemed to bear in his heart strange harmonies and unadventured patterns, and I foresaw for him an end of torture and despair. I had again the feeling that he was possessed of a devil; but you could not say that it was a devil of evil, for it was a primitive force that existed before good and ill" (Maugham, 2008, p. 109).

In this passage, the narrator gives that very characteristic of Strickland, which explains all the synthetic content of the novel. It is ordinary primitivism when the arts were not isolated from the everyday surrounding and mythology. It is an allusion connected with the "duel" of Apollo with Marsyas, when the latter picked up the flute thrown by Athena, which she invented as an imitation of Medusa's sounds. Finally, he summoned Phoebe to the contest and naturally, the faun lost, and the furious God punished the brave man.

Besides, a comparison with the satyr also causes an association with Dionysus, whom they constantly accompany. It must be mentioned that according to Nietzsche's theory, there are two interacting principles - Apollonian and Dionysian. The first one is connected with an individual creative aspiration, with an illusion, a dream, it is separated from everything general and mass, and in its pure form, it deprives the art of life. The Dionysian principle is mass, intoxication, orgiastic self-destruction, death caused by unity with nature. One way or another, but in a pure form, both principles lead to the destruction of the creator, only their combination leads to real and genuine art.

Strickland, an artist who devoted his fate to instinct and invention of a new technique, became a servant of Dionysius. The second victim of the Dionysian principle is Blanche Stroeve, who is destroyed by an internal, paranormal force, imprisoned in the artist's soul:

"Blanche Stroeve was in the cruel grip of appetite. Perhaps she hated Strickland still, but she hungered for him, and everything that had made up her life till then became of no account. She ceased to be a 
woman, complex, kind and petulant, con-

siderate and thoughtless; she was a Mae-

nad. She was desire” (Maugham, 2008,

pp. 121-122).

This is also confirmed by the fact that Blanche is compared with the maenads who are the eternal companions of Dionysus, his violent and raging female retinue.

Very often in the picturesque layer of intermediality three main pictorial genres - landscapes, still lifes and portraits can be found.

The following example deserves consideration:

"...when I came on to the terrace of the hotel no one was stirring. I wandered round to the kitchen, but it was locked, and on a bench outside it a native boy was sleeping. There seemed no chance of breakfast for some time, so I sauntered down to the water-front. The Chinamen were already busy in their shops. The sky had still the pallor of dawn, and there was a ghostly silence on the lagoon. Ten miles away the island of Murea, like some high fastness of the Holy Grail, guarded its mystery" (Maugham, 2008, p. 166).

A sketchy and straightforward image of the island is consistent with the spirit of Gauguin's paintings: not to scatter attention on the details, but to convey its perception of fragments that were supposed to recreate the full colour of the depicted image. So in the novel, the island is depicted in several "strokes", which are mysterious silence, a sleeping little boy and fussy Asians against the background of pale dawn.

Following the traditions of Gauguin, Van Gogh and Cezanne, the author represents several Strickland's still lifes in the novel:

"I remember a still-life of oranges on a plate, and I was bothered because the plate was not round and the oranges were lop-sided" (Maugham, 2008, p. 156).
This statement is the illustration of the fact that the picture itself is created entirely in the spirit of post-impressionism for the reason that there are no correct, natural forms; still life is characterised by a distortion of standard shape. It will subsequently be taken as a basis by surrealists and cubists.

The following passage can serve as a bright example of the use of the portrait in intermediality:

"He had the same absurd appearance

that I remembered. He was a fat little man, with short legs, young still - he could not have been more than thirty - but prematurely bald. His face was perfectly round, and he had a very high colour, a white skin, red cheeks, and red lips. His eyes were blue and round too, he wore large gold-rimmed spectacles, and his eyebrows were so fair that you could not see them. He reminded you of those jolly, fat merchants that Rubens painted"

(Maugham, 2008, p. 80).

W. Maugham's direct mentioning of Rubens helps the reader to imagine the hero of the novel. A typical Flemish bourgeois (blue-eyed, stunted, plump and full of health), in Rubens's works, is portrayed on the pages of the novel.

The study of the intermedial relations of literary and musical texts, where the musical text acts as a referent, and the development of the plot reveals an inextricable connection with the staging of the play, is of great interest:

"Jack and Jill

Went up the hill

To fetch a pail of water.

Jack fell down

And broke his crown

And Jill came tumbling after"

(Barth, 1994, p. 210).

This piece of text is an example of the socalled "verbal music". The musicality of a poem 
is demonstrated through its instrumentation, that is, through a specific selection of repeated sounds: sound repetitions (alliteration and assonances), onomatopoeia, and sound recording (sound and lexical anaphora and epiphora). The rhythmic structure of the presented poetic lines is based on the so-called "varied repetition", which implies not a complete identity of the elements, but only their approximate correlation.

Intermediate connections of fiction and musical texts can lead to creolization of verbal communication by referring to secondary sign recording systems that arise from iconic musical systems.

Consider the next statement:

"Scored rigorously in the accents of speech, the word would appear not as two quarter notes - followed in either case by the ominous silence of that quarter rest on the measure's closing beat" (Barth, 1994, p. 216).

The author, commenting on the mood of the main character, turns to jazz composition and describes in detail the sounds made by various orchestral instruments, also dwelling on the problem of "merging" scattered sounds into a single melody. Furthermore, musical stanzas that make sound the word "water" serve the proof of the ideas presented.

Let us analyze another example to demonstrate the relationship between fiction and musical texts:

"Oh, listen, George," she said; "they're playing the Alma Mater Dolorosa! I love that hymn." And indeed it was most moving to hear her sweet girl voice against the stately horns" (Barth, 1967, p. 127).

The utterance is an example of a more sophisticated musical notation of a polyphonic musical work in the form of students' anthem score. Intermediate inclusions of this kind emphasize the heterogeneity and fragmentation of the literary text, which dynamic interaction with various texts and sign systems in the space of the semiosphere is embodied in the creolization of the message.

While analyzing intermediality, the connection between visual and literary texts can not be ignored. This kind of intermedial relationship finds its illustration in a symbolic image (an emblem as a result of a combination of visual and verbal representation) of the corresponding concept:

"Within a circular field, white above and gules below, the company's initials azure in a loopy script which also forms the field's perimeter. Each loop carrying into one moiety the other's color. The whole resembling, from any distance, a Yang/ Yin done by a patriotic Italo-American spaghetti bender and, closer up, evocative of U.S. imperialism and isolationism at once: US become me and inflated to a global insularity" (Barth, 1979, p. 280).

While explaining the symbolic meaning of the new brand, the hero notes that "at a distance, this sign resembles a graphic image of yin-yang". At the same time, the high promise of such a comparison is reduced by the subsequent use of colloquial vocabulary (bender - revelry).

An essential means of establishing the intermedial relationship between literary and visual texts is the insertion into the verbal space of different literary works with schemes and diagrams as iconic signs, which are based on a relationship of similarity. Ch. Pierce defines the diagram as a representative, which is primarily a conventional iconic sign of relationship (Peirce, 1960). It is the abstractly conditional nature of the image of verbal communication (Usmanova, 2001, p. 290) that allows us to consider this type of intermedial relationship as a means of self-similar organiza- 
tion:

"As for gods on demigods, demigods on demigods, and demigods on mortals, the expectable results can be best represented by a diagram in which gg stands for god, mm mortal, gm (or mg) demigod" (Barth, 1973, p. 190).

The interaction of literary and visual texts can demonstrate their imposition on one another with the subsequent expansion of the meaning of lexemes:

\begin{abstract}
"Indeed, following Aristotle's classification of human actions according to the degree and nature of the agent's volition - my failure to spring to my kinsmen's aid and my preventing Sibyl from rescuing them... fulfills the Pattern: I therefore affirm it, and therefore I'm culpable, morally if not legally, in the Aristotelian sense" (Barth, 1973, p. 183-184).
\end{abstract}

The semantics of the used lexical units follow, fulfill, affirm is expanded as a result of the interweaving of verbal and iconic images of human actions.

Thus, intermediality arises due to the complication of the principles of literary text's organization, which borrows and assimilates the properties of texts belonging to other types of art. This is a particular way of forming a literary text, and a specific methodology for analyzing both a single work of art and the language of art culture as a whole, based on the principles of interdisciplinary studies.

\section{Conclusion}

Intermediality refers to the interaction between literary text and non-verbal sign systems, constituting a multi-code creolized message. The implementation of intermedial relations is carried out through the objectification of various types of art in a literary text at a compositionally-structural and figuratively-stylistic level. The combination of codes of various arts within the framework of a literary text becomes possible due to the mark of openness, which allows us to consider each point of the literary text as a separate "organism", capable of self-development. Using the external semiotic environment of the semiosphere and attracting new codes of perception, the literary text repeatedly recreates and dynamically develops its intermedial structure interacting with other sign systems.

In conclusion, we can state that the undoubted advantage of the theory of intermediality is the allocation of a single space, where certain types of art and their specific texts find their semiotic commensurability, being perceived as carriers and transmitters of encoded meanings.

\section{REFERENCES}

Bakhtin, M. M. (1986).K metodologii gumanitarnykh nauk (To the Methodology of the Humanities, in Russian). Aesthetics of Verbal Creativity, 2, 381-393. Moscow: Art.

Bart, R. (1989). Izbrannye raboty: Semiotika. Poetika. (Selected Works: Semiotics. Poetics, in Russian). Moscow: Progress.

Barth, J. (1967). Giles Goat-Boy, or The Revised New Syllabus. Harmondsworth: Penguin Books.

Barth, J. (1973). Chimera. New York: Fawcett Crest Book.

Barth, J. (1979). Letters. New York: The Hearst Corporation.

Barth, J. (1994). Once Upon a Time: A Floating Opera. Boston; New York: Little, Brown and Company. 
Bekhta, I. A. (2013). Avtors'ke eksperymentatorstvo $v$ anhlomovniy prozi XX stolittya. (Author's Experimentation in English Prose of the XX Century, in Ukrainian). Lviv: PAIS.

Derrida, Zh. (2001). Struktura, znak i hra u dyskursi humanitarnykh nauk (Structure, Sign and Game in the Discourse of the Humanities, in Ukrainian). Word. Sign. Discourse: An Anthology of World Literary and Critical Thought of the Twentieth Century. Lviv: Litopys.

Forster, E. M. (2008). Where Angels Fear to Tread. Rockville, Maryland: Tark Classic Fiction, An Imprint Of ARC Manor.

Hansen-Löve, A. (1983). Intermedialitat und Intertextualitat: Probleme der Korrelation von Wort und Bildkunst - am Beispiel der russischen Moderne. Wiener Slawistischer Almanach, 11, 291-360.

Ilyin, I. P. (1998). Nekotorye kontseptsii iskusstva postmodernizma $v$ sovremennykh zarubezhnykh issledovaniyakh. (Some Concepts of the Art of Postmodernism in Modern Foreign Studies, in Russian). Moscow: Intrada.

Kristeva, Yu. (2004). Izbrannyye trudy: Razrushenie poetiki (Selected Works: The Destruction of Poetics, in Russian). Moscow: ROSSPEN.

Mariniello, S. (2003). Commencements. Intermédialités, 1, 47-62.

Maugham, W. S. (2008). The Moon and Sixpence. Saint Petersburg: KAPO.

Méchoulan, E. (2003). Intermédialités: Le temps des illusions perdues. Intermédialités, 1, 9-27.

Muller, J. E. (2010). Intermediality and Media Historiography in the Digital Era. Acta. univ. sapientiae, film and media studies, 2, 15-38.

Olizko, N. S. (2007). Intertekstual'nost' postmodernistskogo khudozhestvennogo diskursa (na materiale tvorchestva Dzh. Barta). Popytka semiotiko-sinergeticheskogo analiza. (Intertextuality of Postmodern Art Discourse (Based on the Material of J. Barth). Attempt of Semiotic-Synergistic Analysis, in Russian). Chelyabinsk: Encyclopedia.

Peach, J. (2016). Film Text Analysis. Abingdon: Routledge.

Peirce, Ch. S. (1960). Collected Papers. Cambridge: Cambridge-Mass.

Plett, H. F. (1991). Intertextualities. Intertextuality. Research in Text Theory. Berlin: de Gruyter.

Rajewsky, I. O. (2005). Intermediary, Intertextuality, and Remediation. A Literary Perspective on Intermediality, 6, 43-64.

Sedykh, E. V. (2008). K probleme intermedial'nosti. (To the Problem of Intermediality, in Russian). Bulletin of St. Petersburg University, 3(II), 210-214.

Shiniev, E. P. (2009). Intermedial'nost' kak mekhanizm mezhkul'turnoi diffuzii v literature (na primere romanov V.V. Nabokova «Dar»). (Intermediality as a Mechanism of Intercultural Diffusion in Literature (on the Example of the Novels by V.V. Nabokov "Gift”), in Russian). Analytics of Cultural Studies: electronic scientific publication of the Tambov State. University of G. R. Derzhavin, 2(14), 111-116. Retrieved April 18, 2020 from http://analiculturolog.ru/component/resourse/article/journal/2009/23-14/641-00640.html/. 
Tishunina, N. V. (2001). Metodologiya intermedial'nogo analiza $v$ svete mezhdistsiplinarnykh issledovaniy. (Intermediate analysis Methodology in the Light of Interdisciplinary Research, in Russian). The Methodology of Humanitarian Knowledge in the Perspective of the XXI Century: Materials of an International Scientific Conference. Series "Symposium". St. Petersburg: St. Petersburg Philosophical Society, 12, 149-154.

Usmanova, A. R. (2001). Znak ikonicheskiy.
Postmodernizm. (Iconic Sign. Postmodernism, in Russian). Moscow: Interpress service Book House.

Vorobyova, O. P. (2008). Obraz teksta v mental'nykh reprezentatsyyakh: kohnytyvno- semyotycheskyy podkhod. (The image of the text in mental representations: cognitive-semiotic approach), in Russian). Writings in Romance-Germanic, 20, 25-32.

Wolf, W. (1999). Musicalization of Fiction: A Study in the Theory and History of Intermediality. Amsterdam: Rodopy. 